\title{
The Advent of Artificial Intelligence in Diabetes Diagnosis: Current Practices and Building Blocks for Future Prospects
}

\author{
Mr. Mrinmoy Roy ${ }^{1}$, Dr. Mohit Jamwal ${ }^{2}$ \\ ${ }^{1}$ PhD Scholar, Lovely Professional University, Indiamroy2612@gmail.com \\ ${ }^{2}$ Assistant Professor Mittal School of Business, Lovely Professional University, Phagwara, Punjab, India, \\ mohit.21549@lpu.co.in
}




\title{
THE ADVENT OF ARTIFICIAL INTELLIGENCE IN DIABETES DIAGNOSIS: CURRENT PRACTICES AND BUILDING BLOCKS FOR FUTURE PROSPECTS
}

\begin{abstract}
India has the highest proportion of diabetes patients, and it is estimated that there will be 134 Million diabetics in India by 2045 as per IDF. Also, the disease burden is increasing to the young population between ages $25-40$ as more of them are diagnosed positive according to JAMA recently. Moreover, there are only 4.8 Doctors per 10,000 population, and in villages, the ratio is the lowest possible in this country, according to the Indian Journal of Public Health. Therefore, screening \& predicting Diabetes at an early stage remains a priority for clinicians. It reduces the risk of major complications and improves patients' quality of life with diabetes, and builds resilience and well-being amongst other citizens. With the advancement of Computer Science \& Artificial Intelligence, it is now possible to predict diabetes and other such diseases through applying deep learning algorithms in high-quality data sets. This helps in a more accurate and faster diagnosis of Pre-diabetes, Diabetes \& diabetes-related progressive eye diseases. In this study, a systematic review of the Pubmed repository for current practices to diagnose Diabetes based on AI intervention in the Indian context is carried out. Also, a critical analysis was done on various pioneered companies currently offering AI-based Diabetes diagnostic services in India. The study represents different concepts of AI tools used to predict the diseases currently available in India. Although most of the studies were carried out on Diabetic Retinopathy screening, future opportunities can be in several other areas such as Clinical Decision Support, Predictive Population Risk Stratification and Patient Self-Management Tools.
\end{abstract}

Keywords: Diabetes diagnosis, AI-based Diabetes Diagnosis, AI intervention in Diabetes Diagnosis and Management

\section{Introduction}

India is one of seven countries in the SEA Region of the IDF. 463 million people globally have diabetes, and 88 million people in the SEA zone have diabetes, which will grow to 153 million by 2045. (IDF.Org, 2021).

- $\quad$ Complete population for adults: $859,956,100$

- $\quad$ Diabetes incidence in adults: 8.9 percent

- Total cases of adult diabetes: 77,005,6005. (IDF.Org, 2021).

The risk of type 2 diabetes (T2DM) among younger Indians has been increased by sedentary lifestyles and elevated visceral adiposity.

For middle-aged Indians with T2DM, there is a greater risk of biological aging. Among middle-aged Indians, the production of $\mathrm{T} 2 \mathrm{DM}$ is more general. T2DM can accelerate the aging process and can subsequently predispose Indians at a very early age to different age-related complications (Banerjee et al., 2020).

In comparison to the belief of having 7 doctors per 10,000 persons, there were just 4.8 practicing doctors per 10,000 populations available in India in 2014. The majority of the licensed physicians have either retired from the country or have emigrated to practice abroad. It is projected that only by 2030 will the nation be able to reach a ratio of around 6.9 practicing doctors per 10,000 individuals. 
Given these results of the current accessibility of physicians per 10,000 individuals and their growth prospects over the next 15 years, achieving even a modest doctor population ratio of 1:1000 by 2030 seems to be an unlikely task (Potnuru, 2017).

Early diabetes screening and prediction is often a priority for physicians since it decreases the likelihood of significant complications and increases the quality of life of diabetes patients, and builds resilience and wellbeing among other people (Trikkalinou, 2017).

Table 1: Common AI Approaches used in Diabetes Care

\begin{tabular}{|c|c|c|c|}
\hline \multicolumn{4}{|c|}{ Common AI Approaches used in Diabetes Care } \\
\hline $\begin{array}{l}\text { Sl } \\
\text { No }\end{array}$ & Method & How it works & Applications \\
\hline 1 & Multilayer perceptron & $\begin{array}{l}\text { Neurons in each layer are connected to all } \\
\text { neurons in the next layer, consisting of neurons } \\
\text { in the input layer, output layer, and several } \\
\text { hidden layers, making each layer completely } \\
\text { connected to the next. Learn by the form of } \\
\text { 'backpropagation.' }\end{array}$ & $\begin{array}{l}\text { Prediction models, patient } \\
\text { self-management tools }\end{array}$ \\
\hline 2 & $\begin{array}{l}\text { Convolutional neural } \\
\text { network }(\mathrm{CNN})\end{array}$ & $\begin{array}{l}\text { Composed of several neuron layers with } \\
\text { neurons in the convolution layer that look at } \\
\text { small patches of the input image at a time, like a } \\
\text { filter, and are transformed across the entire input } \\
\text { image, and parameters are shared throughout the } \\
\text { image. Learn by the form of 'backpropagation' } \\
\text { The presence of unique features across space is } \\
\text { detected by each CNN layer, detecting more } \\
\text { high-level features as they move forward. }\end{array}$ & Retinal Screening \\
\hline 3 & Random forest & $\begin{array}{l}\text { Creates an assembly of trees of judgment. A } \\
\text { random collection of features for evaluating root } \\
\text { nodes and splits are considered in each tree. }\end{array}$ & $\begin{array}{l}\text { Retinal Screening, } \\
\text { decision support, } \\
\text { prediction models, patient } \\
\text { self-management tools }\end{array}$ \\
\hline 4 & $\begin{array}{l}\text { Fuzzy logic/ fuzzy } \\
\text { system }\end{array}$ & $\begin{array}{l}\text { Provide a probability value between } 0 \text { and } 1 \text { for } \\
\text { membership of a certain class rather than a } \\
\text { deterministic decision }(0 \text { or } 1) \text {. }\end{array}$ & $\begin{array}{l}\text { Retinal screening, } \\
\text { decision support, sensors, } \\
\text { and artificial pancreas }\end{array}$ \\
\hline 5 & $\begin{array}{l}\text { Support vector } \\
\text { machine (SVM) }\end{array}$ & $\begin{array}{l}\text { Method of classification for binary results (not } \\
\text { often used for multiclass problems, but } \\
\text { techniques for multiclass SVM exist). Works by } \\
\text { adding information to a high-dimensional space } \\
\text { and finds a hyperplane separating the best two } \\
\text { groups (that maximizes the distance between the } \\
\text { plane and nearby data points, or margin) }\end{array}$ & $\begin{array}{l}\text { Retinal Screening, } \\
\text { decision support, } \\
\text { prediction models, patient } \\
\text { self-management tools }\end{array}$ \\
\hline
\end{tabular}




\begin{tabular}{|l|l|l|l|}
\hline 6 & Logistic regression & $\begin{array}{l}\text { Method for binary outcome classification. } \\
\text { Predicts the possibility of an outcome }(0 \text { or 1) } \\
\text { depending on the characteristics. Learn the } \\
\text { model coefficients by the calculation of } \\
\text { maximum probability. Searches for a line or } \\
\text { hyperplane that best represents the points of } \\
\text { data. }\end{array}$ & Prediction models \\
\hline 7 & $\begin{array}{l}\text { Natural language } \\
\text { processing }\end{array}$ & $\begin{array}{l}\text { Computational tools and techniques for human } \\
\text { language processing, interpretation, and } \\
\text { inference efficiency. }\end{array}$ & Prediction models \\
\hline 8 & $\begin{array}{l}\text { K-nearest neighbors } \\
\text { algorithm }\end{array}$ & $\begin{array}{l}\text { Categorizes input data using its k nearest } \\
\text { neighbors into several groups. }\end{array}$ & $\begin{array}{l}\text { Retinal Screening, } \\
\text { decision support, } \\
\text { prediction models, patient } \\
\text { self-management tools }\end{array}$ \\
\hline
\end{tabular}

This helps in a more accurate and faster diagnosis of Pre-diabetes, Diabetes \& diabetes-related progressive eye diseases. AI's ability to rapidly interpret and process enormous amounts of data into simple, actionable guidance. AI has significant potential to improve the screening, diagnosis, and management of patients with diabetes (Lo'pez B. et al., 2018).

\section{Background}

In the 2019 IDF South-East Asia (SEA) area, 88 million adults (20-79) live with diabetes. By 2045, this number is expected to grow to 153 million. More than half ( 57 percent) of people with diabetes in the IDF SEA Area are undiagnosed. In 2019, diabetes accounted for 1.2 million deaths in the IDF SEA area. Hyperglycaemia in pregnancy affects 1 in 4 live births in the IDF SEA Area. In 2019, USD 8.1 billion was spent on health care for people with diabetes, the second-lowest expense among all IDF regions in 2019. (IDF Diabetes Atlas 9th Edition 2019).

Table 2 : Countries with maximum number of people with Diabetes (20-79 years)

Top 5 Countries for Number of People with Diabetes (20-79 Years, 2019)

\begin{tabular}{|l|l|}
\hline & Millions \\
\hline India & 77.0 \\
\hline Bangladesh & 8.4 \\
\hline Sri Lanka & 1.2 \\
\hline Nepal & 0.7 \\
\hline Mauritius & 0.2 \\
\hline
\end{tabular}

The rapid urbanization, sedentary lifestyle, high-calorie diet, visceral adiposity, and high genetic predisposition have been established as the key factors that increase the risk of type 2 diabetes mellitus (T2DM) among Indians at a much younger age and a lower body mass index (BMI) than the western population (R. Pradeepa et al., 2011). Various population-based studies have shown that in age groups below 50 years of age, the average onset of T2DM among Indians is steadily growing (R. Pradeepa et al., 2011, Kumar et al., 2018). Chronic 
hyperglycemia, dyslipidemia, and increased insulin resistance are the key pathological features of T2DM, contributing to a plethora of metabolic and molecular alterations, eventually leading to the development of diabetes-associated vascular complications (Donath, 2014)

One of the most significant causes of the backwardness of Indian health status is the relative inaccessibility of primary health care and undernourishment among children in India. The total number of licensed physicians rose from approximately 75,594 in 1960 , to 393,424 in $1990,566,102$ in $2000,824,673$ in 2010 , and to 943,529 by 2014. (MCI, 2019). The rapid growth of medical doctors through the recent expansion of private medical education has not dramatically changed the population's basic health outcomes. The key factors are: one, the recent rise in the number of medical practitioners is not sufficient to balance the risk's very rapid increase in overall health care needs, rising population; two, the higher capabilities and expectations of the medical practitioners, especially specialist doctors, do not match with the primary health care requirements and affordability of the majority of people in rural areas; and three, increase in the number of registered doctors (stock) do not reflect the actual availability of doctors in the country, i.e., the stock is wrongly viewed as the availability of doctors in the country is unaware of attrition due to retirement, emigration, change of occupation, etc. The Government of India has 7 doctors per 10,000 communities, according to the WHO and the Ministry of Health and Family Welfare (WHO, 2019). This ratio, however, is derived from the registration stock of doctors accumulated in India, including those doctors who were trained and registered since the beginning of the 20th century (MCI, 2019). This has not been updated to strength due to retirement, discontinuation of practice, emigration, and death of doctors.

The key purpose of early diagnosis and treatment of diabetes is the quality of life (QoL). As symptoms begin to arise or comorbidities coexist, diabetic QoL gets worse. Coronary arterial disease accompanied by renal failure, blindness, and the combination of micro-and macrovascular complications and in some studies of sexual dysfunction was prevalent among the complications in health-related quality of life (HRQoL) reduction, but not related to risk factors (genetic, birth weight, or others). In fact, many are the comorbidities that further deteriorate the effect of diabetes in a patient's life. Obesity, hypertension, dyslipidemia, depression, and arthritis are among them. Among them, obesity, hypertension, dyslipidemia, depression, and arthritis are the most common.

The lack of real-time, key health knowledge required to make informed decisions associated with intensive treatment and strict management of diabetes also hampers optimal care for people with diabetes (PWDs). While advances in technology provide many people in many fields with unparalleled and inexpensive access to critical information, their effect on the treatment of patients with diabetes seems somewhat limited. The rapid extension of medical expertise compounds the complexities of real-time information on diabetes treatment. Rapid developments in artificial intelligence (AI) offer the promise of making accessible for the treatment of PWDs both real-time structured and unstructured health data.

The Turing Archive defines AI for the History of Computing as " the science of making computers do things that require intelligence when done by humans." AI covers a wide range of approaches to simulating human intelligence and performing different tasks of reasoning, such as visual perception, recognition of speech, analytics, decision-making, and language translation. The scope of AI methods is used by cognitive systems to expand and scale human awareness and expertise by allowing humans to easily exploit large sources of knowledge to solve problems. Today, in order to meet customer demand in every sector, including health care, $\mathrm{AI}$ uses vast quantities of vital information. 
A 2017 study found that 68 percent of developers and publishers of mobile health apps agree that diabetes continues to be the single most significant area of health care with the greatest business potential for digital health solutions in the near future and that 61 percent see AI as the most disruptive technology shaping the digital health sector. This paper aims to better understand what important AI developments can be applicable to PWDs, their primary care clinicians today.

\section{Method}

The study team conducted a predefined, online PubMed search of publicly available sources of information using the search terms "diabetes" and "artificial intelligence (AI)." To identify articles with clinically relevant, high-impact diabetes AI applications, the team excluded manuscripts with publication dates before 2010 and those whose purpose was primarily technical in nature (e.g., focused solely on AI algorithm development). The first-pass search identified a total of 20 clinically relevant abstracts. The additional review excluded 9 as duplicative or primarily technical. The second-pass review yielded a total of 11 unique, clinically relevant articles researching the direct application of AI in diabetes prevention, diagnosis, and treatment. The information was then collated and classified. The research was conducted between Dec 2020 and Feb of 2021.

\section{Results}

A total of 11 clinically important and high-impact articles published related to the field of applied AI in diabetes care were obtained from the PubMed search. The goal of the AI applications was to enhance a wide range of diabetes care, from diabetes screening and diagnosis to monitoring and treatment, including applications, devices, and systems to support patients, clinicians, and health systems. The published papers included in this search were of high clinical impact in that they aimed to establish and evaluate AI approaches that could have a major impact on diabetes treatment in the areas of access, precision, quality, affordability, speed, and patient, clinician, and caregiver satisfaction. An analysis of the high-impact papers indicates that AI applications seek to turn diabetes treatment into four main areas: automated retinal screening, support for clinical decision-making, stratification of predictive population risk, and tools for patient self-management, as outlined in Table 1. In these studies, a diverse and complex collection of AI methods and cognitive computing systems were employed. The more popular AI approaches mentioned in the research are specified in Table 2, and their clinical applications in diabetes care are listed.

In this study, a systematic review of the PubMed repository for current practices to diagnose Diabetes based on AI intervention in the Indian context is carried out. As seen in table 3 here:

Table 3: Current practices to diagnose Diabetes based on AI intervention in India

\begin{tabular}{|c|c|c|c|}
\hline $\begin{array}{l}\text { Details of the journal/ Book / Book } \\
\text { chapter/ website link }\end{array}$ & $\begin{array}{l}\text { Year of } \\
\text { Publication }\end{array}$ & $\begin{array}{l}\text { Indexing of journal } \\
\text { (Scopus/ SCI index } \\
\text { etc.) }\end{array}$ & $\begin{array}{l}\text { Main findings or conclusion relevant to } \\
\text { proposed research work }\end{array}$ \\
\hline $\begin{array}{l}\text { Mohan Rema, Sundaram Premkumar, } \\
\text { Balaji Anitha, Raj Deepa, Rajendra } \\
\text { Pradeepa, and Viswanathan Mohan; } \\
\text { Prevalence of Diabetic Retinopathy in } \\
\text { Urban India: The Chennai Urban } \\
\text { Rural Epidemiology Study (CURES) } \\
\text { Eye Study, I; Investigative } \\
\text { Ophthalmology \& Visual Science, } \\
\text { July 2005, Vol. 46, No. } 7 \text { Invest } \\
\text { Ophthalmol Vis Sci. 2005;46:2328- } \\
\text { 2333) DOI:10.1167/iovs.05-0019 }\end{array}$ & Jul- & iovs.arvojournals.org & $\begin{array}{l}\text { This research shows that diabetic retinopathy } \\
\text { prevalence in urban South Indians is lower } \\
\text { than in other ethnic groups. However, DR is } \\
\text { likely to pose a public health burden in India } \\
\text { due to a large number of diabetic subjects; } \\
\text { regular retinal examination is therefore } \\
\text { mandatory for early-stage DR detection. }\end{array}$ \\
\hline
\end{tabular}




\begin{tabular}{|c|c|c|c|}
\hline $\begin{array}{l}\text { Shankaracharya, Devang Odedra, } \\
\text { Subir Samanta and Ambarish S. } \\
\text { Vidyarthi, Computational } \\
\text { Intelligence-Based Diagnosis Tool for } \\
\text { the Detection of Prediabetes and Type } \\
2 \text { Diabetes in India, The Review of } \\
\text { Diabetic Studies; Vol 9, No 1, 2012 } \\
\text { DOI 10.1900/RDS.2011.9.55 }\end{array}$ & & www.The-RDS.org & $\begin{array}{l}\text { This study describes a highly accurate } \\
\text { machine learning prediction method for } \\
\text { high-accuracy detection of prediabetic, } \\
\text { diabetic, and non-diabetic individuals. In } \\
\text { hospitals or diabetes prevention services, the } \\
\text { instrument could be used for large-scale } \\
\text { screening. }\end{array}$ \\
\hline $\begin{array}{l}\text { Kim Ramasamy \& Rajiv Raman \& } \\
\text { Manish Tandon, Current State of Care } \\
\text { for Diabetic Retinopathy in India; } \\
\text { Curr Diab Rep (2013) 13:460-468 } \\
\text { DOI 10.1007/s11892-013-0388-6 }\end{array}$ & May-13 & $\begin{array}{l}\text { Springer } \\
\text { Science+Business } \\
\text { Media New York } \\
2013\end{array}$ & $\begin{array}{l}\text { Given the country's diverse geographic } \\
\text { characteristics and the shortage of } \\
\text { ophthalmologists, telescreening seems to be } \\
\text { a very promising method in India. An } \\
\text { approach to detecting at least sight- } \\
\text { threatening retinopathy rather than any } \\
\text { retinopathy is believed to be more useful } \\
\text { until India has a sufficient number of trained } \\
\text { vitreoretinal specialists or all } \\
\text { ophthalmologists become aware of diabetic } \\
\text { retinopathy for medical management. There } \\
\text { is an important need to raise awareness of } \\
\text { diabetes and its associated complications } \\
\text { while strengthening primary diabetes } \\
\text { treatment. It is important that health care } \\
\text { providers connect with each other in the } \\
\text { management of patients to ensure that high- } \\
\text { risk individuals are screened early. The best } \\
\text { treatment available today for diagnosed } \\
\text { cases with diabetic retinopathy is on par with } \\
\text { that available in developed countries } \\
\text { worldwide. However, this treatment is still } \\
\text { not available to many people, especially } \\
\text { those in rural areas. Patients may have } \\
\text { greater access to adequate screening and } \\
\text { treatment by technical advancements and } \\
\text { thereby reduce unnecessary blindness. }\end{array}$ \\
\hline $\begin{array}{l}\text { Gadkari et al., Prevalence of diabetic } \\
\text { retinopathy in India: The All India } \\
\text { Ophthalmological Society Diabetic } \\
\text { Retinopathy Eye Screening Study } \\
\text { 2014 Indian J Ophthalmol. 2016 Jan; } \\
\text { 64(1): } 38-44 . \\
\text { doi: } 10.4103 / 0301-4738.178144\end{array}$ & Jan-16 & $\begin{array}{l}\text { Indian Journal } \\
\text { Ophthalmology }\end{array}$ & $\begin{array}{l}\text { In 2014, the All India Ophthalmological } \\
\text { Society (AIOS) took an initiative to detect } \\
\text { the prevalence of DR in eye clinics across } \\
\text { the length and breadth of the country among } \\
\text { people with diabetes. The exercise marked } \\
\text { the first pan-India effort to take the first } \\
\text { steps against the DR blindness issue outside } \\
\text { the nation. While the study aimed to } \\
\text { determine the prevalence and explore risk } \\
\text { factors among known diabetics for the } \\
\text { development of DR, it also sought to identify } \\
\text { weaknesses in the current case detection } \\
\text { process to strengthen future screening } \\
\text { programs. }\end{array}$ \\
\hline 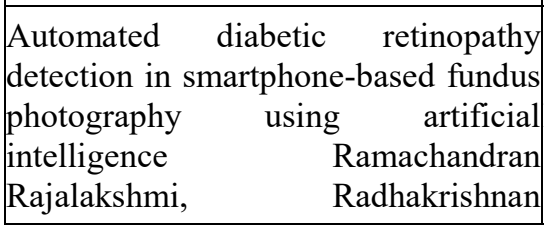 & M & Springer Nature & $\begin{array}{l}\text { In this review, fundus photography evaluates } \\
\text { the role of artificial intelligence (AI)-based } \\
\text { automated software for diabetic retinopathy } \\
\text { (DR) and sight-threatening DR (STDR) } \\
\text { detection using a smartphone-based interface }\end{array}$ \\
\hline
\end{tabular}




\begin{tabular}{|l|l|l|}
\hline $\begin{array}{l}\text { Subashini, Ranjit Mohan Anjana, } \\
\text { Viswanathan Mohan Eye (2018) } \\
\begin{array}{l}32: 1138-1144 \\
\text { https://doi.org/10.1038/s41433-018- } \\
0064-9\end{array}\end{array}$ & $\begin{array}{l}\text { and validates it against grading by an } \\
\text { ophthalmologist. Grading by the automated } \\
\text { ophthalmologist. FOP mobile retinal } \\
\text { imaging automated AI analysis has a very } \\
\text { high sensitivity for DR and STDR detection. } \\
\text { It can therefore be an initial method for mass } \\
\text { retinal screening in people with diabetes. }\end{array}$ \\
\hline
\end{tabular}

Table 4: Different Pioneered companies currently offering AI-based Diabetes diagnostic services in India

\begin{tabular}{|c|c|c|c|}
\hline $\begin{array}{l}\text { Details of the journal/ Book / Book } \\
\text { chapter/ website link }\end{array}$ & $\begin{array}{l}\text { Year } \\
\text { Publicatio }\end{array}$ & $\begin{array}{l}\text { findexing of journal } \\
\text { (Scopus/ SCI index etc.) }\end{array}$ & $\begin{array}{l}\text { Main findings or } \text { conclusion } \\
\text { relevant to proposed research work }\end{array}$ \\
\hline $\begin{array}{l}\text { Gulshan et al., JAMA Ophthalmol. } \\
\text { 2019;137(9):987-993. } \\
\text { doi:10.1001/jamaophthalmol.2019.2004 } \\
\text { Published online June 13, } 2019 .\end{array}$ & Jun-19 & $\begin{array}{lr}\text { Google } & \text { Research, } \\
\text { Mountain } & \text { View, } \\
\text { California } & \\
\text { (jamaophthalmology.com) }\end{array}$ & $\begin{array}{l}\text { This study shows that in a } \\
\text { prospective setting, the automated } \\
\text { DR system generalizes to this } \\
\text { population of Indian patients and } \\
\text { demonstrates the feasibility of } \\
\text { extending screening services using an } \\
\text { automated DR grading system. }\end{array}$ \\
\hline $\begin{array}{l}\text { Natarajan et al., JAMA Ophthalmol. } \\
\text { 2019;137(10):1182-1188. } \\
\text { doi:10.1001/jamaophthalmol.2019.2923 } \\
\text { Published online August 8, } 2019 .\end{array}$ & Aug-19 & jamaophthalmology.com & $\begin{array}{l}\text { In community screening for referable } \\
\text { diabetic retinopathy with a } \\
\text { smartphone-based fundus camera, } \\
\text { these pilot study results show } \\
\text { promise in the use of an offline AI } \\
\text { device. In remote areas where } \\
\text { ophthalmology services are not } \\
\text { available, the use of AI will allow } \\
\text { screening for referable diabetic } \\
\text { retinopathy. } \\
\text { This research was performed on } \\
\text { patients with diabetes attending a } \\
\text { clinic that provides the community } \\
\text { with curative services at the primary } \\
\text { level. However, to expand the } \\
\text { findings to general population } \\
\text { screening, a study with a larger } \\
\text { sample size may be required. }\end{array}$ \\
\hline $\begin{array}{l}\text { Ramachandran Rajalakshmi, The } \\
\text { impact of artificial intelligence in } \\
\text { screening for diabetic retinopathy in } \\
\text { India Eye } \quad(2020) \quad 34: 420-421 \\
\text { https://doi.org/10.1038/s41433-019- } \\
0626-5\end{array}$ & Dec-19 & Springer Nature & $\begin{array}{l}\text { As per this study, it appears that real- } \\
\text { time deployment of AI in screening } \\
\text { for DR is feasible. It fits in with the } \\
\text { current trend of telemedicine for } \\
\text { screening, and automated retinal } \\
\text { image analysis extends opportunities } \\
\text { to screening in more remote areas. } \\
\text { AI-assisted DR algorithms could } \\
\text { potentially expedite early detection of } \\
\text { DR at the primary care level and } \\
\text { would be helpful in screening large } \\
\text { numbers of people with diabetes in } \\
\text { low and middle-income countries like }\end{array}$ \\
\hline
\end{tabular}




\begin{tabular}{|c|c|c|c|}
\hline & & & India. \\
\hline $\begin{array}{l}\text { Sosale B, Aravind SR, Murthy H, et al. } \\
\text { Simple, Mobile-based Artificial } \\
\text { Intelligence Algorithm in the detection } \\
\text { of Diabetic Retinopathy (SMART) } \\
\text { study. BMJ Open Diab Res Care } \\
\text { 2020;8:e00892. doi:10.1136/bmjdrc- } \\
\text { 2019-000892 }\end{array}$ & Jan-20 & $\begin{array}{l}\text { BMJ Open Diabetes } \\
\text { Research \& Care }\end{array}$ & $\begin{array}{l}\text { In the diagnosis of diabetic } \\
\text { retinopathy (DR) using non- } \\
\text { mydriatic (NM) retinal photos, this } \\
\text { study evaluated the efficiency of the } \\
\text { offline smartphone-based Medios } \\
\text { artificial intelligence (AI) algorithm. } \\
\text { In the detection of RDR using NM } \\
\text { retinal images, the Medios AI has } \\
\text { high sensitivity and specificity. }\end{array}$ \\
\hline $\begin{array}{l}\text { Bardhan et al., CONNECTING } \\
\text { SYSTEMS, DATA, AND PEOPLE: A } \\
\text { MULTIDISCIPLINARY RESEARCH } \\
\text { ROADMAP FOR CHRONIC } \\
\text { DISEASE MANAGEMENT }\end{array}$ & Mar-20 & MIS Quarterly & $\begin{array}{l}\text { It Showcases research that focuses } \\
\text { and contributes to the role of AI and } \\
\text { analytics in the management and } \\
\text { prevention of chronic diseases. We } \\
\text { give a summary below of emerging } \\
\text { trends from previous studies on the } \\
\text { use of analytics in the management of } \\
\text { chronic diseases. Since research on } \\
\text { health information systems has been } \\
\text { reviewed in prior work, the emphasis } \\
\text { is mainly on prior research on } \\
\text { analytics; although the focus is on } \\
\text { prior research on analytics } \\
\text { The treatment of chronic diseases is } \\
\text { not limited to these past reviews. } \\
\text { Furthermore, this paper leverages a } \\
\text { "connecting systems, data, and } \\
\text { people" structure to provide a } \\
\text { roadmap for future research in this } \\
\text { space. }\end{array}$ \\
\hline $\begin{array}{l}\text { Gunasekeran et al., Artificial } \\
\text { intelligence for diabetic retinopathy } \\
\text { screening, prediction and management; } \\
\text { Curr Opin Ophthalmol. } 2020 \\
\text { Sep;31(5):357-365. } \\
\text { doi:10.1097/ICU.0000000000000693 }\end{array}$ & Sep-20 & Pubmed & $\begin{array}{l}\text { This paper summarizes developments } \\
\text { in artificial intelligence and } \\
\text { teleophthalmology for diabetic } \\
\text { retinopathy screening, including real- } \\
\text { world artificial intelligence } \\
\text { implementations and cost- } \\
\text { effectiveness studies. In addition, } \\
\text { initial research on the use of artificial } \\
\text { intelligence models for risk } \\
\text { stratification and management of } \\
\text { DME for diabetic retinopathy is } \\
\text { outlined alongside possible future } \\
\text { guidance. Finally, in answer to } \\
\text { COVID 19, the need for artificial } \\
\text { intelligence adoption within } \\
\text { ophthalmology is addressed. }\end{array}$ \\
\hline
\end{tabular}


A critical analysis done on various pioneered companies currently offering AI-based Diabetes diagnostic services in India. As seen in table 5 here:

Table 5: A Critical Analysis of various pioneered companies currently offering AI-based Diabetes diagnostic services in India

\begin{tabular}{|c|c|}
\hline $\begin{array}{l}\text { Details of the journal/ Book / Book chapter/ } \\
\text { website link }\end{array}$ & $\begin{array}{l}\text { Main findings or conclusion relevant to proposed research } \\
\text { work }\end{array}$ \\
\hline Map my Genome https://mapmygenome.in/ & $\begin{array}{l}\text { The Genomepatri test gives individuals insight into their } \\
\text { genomes to help them make proactive decisions about their } \\
\text { health. Mapmygenome is a molecular diagnostic company. } \\
\text { The company offers personalized health solutions that help } \\
\text { people get to know about themselves based on genetic tests. } \\
\text { Mapmygenome provides actionable steps for individuals and } \\
\text { their physicians towards a healthier life by combining genetic } \\
\text { health profile \& health history with genetic counselling. With } \\
\text { proprietary AI/ML-based data analysis algorithms, they } \\
\text { provide genomic assessment for more than } 200 \text { conditions. }\end{array}$ \\
\hline $\begin{array}{l}\text { Microsoft India (https://news.microsoft.com/en- } \\
\text { in/tag/launch-microsoft-intelligent-network-for- } \\
\text { eyecare-mine-government-health-it-conference-and- } \\
\text { exihibition/) }\end{array}$ & $\begin{array}{l}\text { Microsoft India partnered with L V Prasad Eye Institute and } \\
\text { collaborated with global experts to launch an AI platform for } \\
\text { Microsoft Intelligent Network for Eyecare (MINE) to provide } \\
\text { healthcare by screening for eye problems and preventing } \\
\text { 'avoidable blindness' for children with eye problems. }\end{array}$ \\
\hline $\begin{array}{l}\text { Google } \\
\text { (https://www.healthcareitnews.com/news/google- } \\
\text { verify-using-ai-screen-diabetic-retinopathy-india) }\end{array}$ & $\begin{array}{l}\text { Google has trained its image recognition algorithms in } \\
\text { conjunction with Aravind Eye Care Systems to detect signs of } \\
\text { diabetic-related eye problems and a human doctor, leading to } \\
\text { timely intervention and preventing blindness. Physicians will } \\
\text { be able to grade diabetic retinopathy to a certain level of } \\
\text { identification, mainly for screening, with AI and Google's } \\
\text { machine learning algorithm. }\end{array}$ \\
\hline DRISHTI from SigTuple.com & $\begin{array}{l}\text { Drishti is a SaaS platform for diabetic retinopathy (DR) } \\
\text { screening (as per ICO2017 standards) and has the ability to } \\
\text { use fundus images to flag age-related macular degeneration } \\
\text { (AMD) and glaucoma. Drishti DR is a registered SaMD } \\
\text { product, a cloud-based artificial intelligence (AI) system } \\
\text { capable of automated image analysis captured from the } \\
\text { Fundus Diabetic Retinopathy screening camera (DR). To offer } \\
\text { end-to-end reporting, the software can be integrated with a } \\
\text { Fundus camera. }\end{array}$ \\
\hline Orbuculum & $\begin{array}{l}\text { Orbuculum utilizes artificial intelligence through genomic } \\
\text { data to predict diseases such as cancer, diabetes, neurological } \\
\text { disorders, and cardiovascular diseases. It serves as a fast, } \\
\text { accurate, highly cost-effective process for diagnosing and } \\
\text { predicting diseases. We are a reliable solution that can meet } \\
\text { the needs of the poor and save their lives by diagnosis at a } \\
\text { very early stage, reducing the time taken for diagnosis of } \\
\text { diseases and at the same time predicting the onset of diseases } \\
\text { in the future. With an increasing amount of genomic data } \\
\text { being generated globally, our tool is essential for extracting } \\
\text { meaningful information from this data and putting it into }\end{array}$ \\
\hline
\end{tabular}




\begin{tabular}{|c|c|}
\hline & practice. \\
\hline Arya-ai (arya.ai) & $\begin{array}{l}\text { In drug discovery, diagnostics, and personalized medicine, } \\
\text { Arya ai utilizes deep learning technology. }\end{array}$ \\
\hline Inayo (www.inayo.in) & $\begin{array}{l}\text { Inayo is a personal assistant to patients suffering from } \\
\text { diabetes. Artificial Intelligence and Machine Learning are at } \\
\text { the core of Inayo. In consultation with senior diabetologists, } \\
\text { nutritionists, diabetes educators, podiatrists, ophthalmologists, } \\
\text { and endocrinologists, more than half a million combinations of } \\
\text { unique diabetes profiles have been developed, and algorithms } \\
\text { developed. The core components of the diabetes management } \\
\text { program are as follows: diabetes education and advice, self- } \\
\text { care and lifestyle management, home comfort medication and } \\
\text { diagnostic tests, and expert monitoring. }\end{array}$ \\
\hline $\begin{array}{l}\text { Details of the journal/ Book / Book chapter/ website } \\
\text { link }\end{array}$ & $\begin{array}{l}\text { Main findings or conclusion relevant to proposed research } \\
\text { work }\end{array}$ \\
\hline $\begin{array}{l}\text { DRISTi from Artelus (Artificial Learning Systems } \\
\text { India Pvt. Ltd) https://artelus.com/products.php\#dristi }\end{array}$ & $\begin{array}{l}\text { Diabetic Retinopathy Screening (DRISTi) (CE Class 1) is an } \\
\text { AI product designed to instantly detect the early presence of } \\
\text { Diabetic Retinopathy (DR) in patients during eye testing. AI } \\
\text { on a Chip Artelus has taken DR screening to the most remote } \\
\text { areas of India by cutting the cord and creating the first of its } \\
\text { kind. This offline solution does not rely on the internet or the } \\
\text { cloud and brings the forgotten billions who need this service } \\
\text { to the Point of Care diagnostics. }\end{array}$ \\
\hline ChironX (www.chironx.ai) & $\begin{array}{l}\text { ChironX works in the area of medical diagnostics powered by } \\
\text { AI. It offers diagnostic software from medical images to } \\
\text { diagnose complex diseases. An image processing technique is } \\
\text { currently used to diagnose diabetic retinopathy, hypertensive } \\
\text { retinopathy, and other retinal disorders. To examine retinal } \\
\text { fundus images in seconds, it uses deep learning and AI in its } \\
\text { apps. It allows doctors and even non-specialists to have a more } \\
\text { rapid diagnosis with far more detail by annotating lesions and } \\
\text { anomalies. It has more than } 95 \text { percent clinical sensitivity, and } \\
\text { the findings are confirmed scientifically and statistically. Age- } \\
\text { related macular dege is one of the other diseases it can detect. } \\
\text { Some of the other diseases it can detect are age-related } \\
\text { macular degeneration, diabetic macular edema, and more. }\end{array}$ \\
\hline
\end{tabular}




\begin{tabular}{|c|c|}
\hline BeatO (www.beatoapp.com) & $\begin{array}{l}\text { Since } 2015 \text {, this AI-based software has been supporting } \\
\text { diabetic patients. It has been downloaded over } 100,000 \text { times } \\
\text { on the Play Store, having supported more than } 50,000 \\
\text { customers in over } 1500 \text { cities since last year. The app is built } \\
\text { around the needs of an average diabetes-positive Indian } \\
\text { middle-class customer. In addition to controlling diets by } \\
\text { recommending diabetic-friendly foods and cereals, it uses AI } \\
\text { and data analytics to provide appropriate nutrition resources to } \\
\text { help users recognise safe foods, the amount of food, and } \\
\text { identify the patient's glycemic index. The software comes with } \\
\text { a glucometer, which can be plugged for reading into a } \\
\text { smartphone. The reading is then saved in the app and can be } \\
\text { used for managing diet by suggesting diabetic-friendly food } \\
\text { and cereals. The app comes with a glucometer which can be } \\
\text { plugged into a smartphone to take the reading. The reading is } \\
\text { then saved in the app and can be used for further guidance and } \\
\text { intervention in case of an emergency. The app can be synced } \\
\text { to various fitness trackers such as Fitbit and others. }\end{array}$ \\
\hline HealthifyMe (www.healthifyme.com) & $\begin{array}{l}\text { This start-up focused on AI works on diseases of the lifestyle } \\
\text { such as obesity, hypertension, and diabetes. It features AI- } \\
\text { enabled nutrition coach Ria who talks to people to assist them } \\
\text { very effectively with diabetes-related queries. Ria is an AI- } \\
\text { enabled conversational nutritionist who blends the power of } \\
\text { technology to have measurable effects with real human } \\
\text { services. Ria uses key lessons learned from } 150 \text { million } \\
\text { monitored meals from HealthifyMe and more than } 10 \text { million } \\
\text { message exchanges between coaches and customers to } \\
\text { develop over time. It indicates that the consumer of the food } \\
\text { plan for diabetes helps them keep the condition under control. }\end{array}$ \\
\hline LiveHealth (www.livehealth.in) & $\begin{array}{l}\text { This start-up focused on AI provides clients with diagnostics } \\
\text { through automation. As soon as they are available, this } \\
\text { company provides reports to patients or organisations online. } \\
\text { It also makes online payments, tracks all patient operations in } \\
\text { real-time, and allows doctors to access patient details at any } \\
\text { time. With only one click, doctors can also sign their patient } \\
\text { reports. In providing medical diagnostics, their priority is full } \\
\text { digitization and automation, due to which report entry errors } \\
\text { are entirely eliminated. }\end{array}$ \\
\hline $\begin{array}{l}\text { Neurosynaptic Communications Pvt Ltd } \\
\text { (www.neurosynaptic.com) }\end{array}$ & $\begin{array}{l}\text { They aim to make health care available through their start-up } \\
\text { to all the masses. It offers high-quality Online Healthcare } \\
\text { Delivery Solutions from ReMeDi. It remotely gathers } \\
\text { knowledge about different physiological aspects of patients } \\
\text { and provides them with a diagnosis. They make the entire } \\
\text { process of diagnosis affordable by doing this. They currently } \\
\text { operate in four cities with a primary emphasis on the delivery } \\
\text { of healthcare. So far, the bulk of their work has been in } \\
\text { schools, and they also have an app-based tool for parents to } \\
\text { prepare their children's healthy meals. }\end{array}$ \\
\hline
\end{tabular}




\begin{tabular}{|l|l|}
\hline OnliDoc & $\begin{array}{l}\text { OnliDoc utilizes AI and ML for end-to-end medical diagnosis. } \\
\text { It has a phone app used to locate physicians, book } \\
\text { appointments, and shop prescriptions and medical records. It } \\
\text { has an artificial intelligence and symptom checker for deep } \\
\text { learning and offers reports online. It utilizes AI and deep } \\
\text { learning to assist in the choice of care and advises the first } \\
\text { steps to be taken. Their software is available for iOS and the } \\
\text { Play Store. }\end{array}$ \\
\hline Aadar & $\begin{array}{l}\text { Healthcare begins with preventive care, which simply means } \\
\text { taking reasonable measures to nip illnesses in the bud and } \\
\text { keeping a check on different health conditions. AADAR is one } \\
\text { such venture operating in the preventive healthcare space } \\
\text { inspired by Ayurveda." AADAR provides herb-based } \\
\text { products such as protein shortages, blood sugar, indigestion, } \\
\text { cholesterol, and obesity to curb lifestyle ailments. }\end{array}$ \\
\hline
\end{tabular}

\section{Future Prospects}

Although majority of the studies are carried out on Diabetic Retinopathy screening, future opportunities can be in several other areas such as Clinical Decision Support, Predictive Population Risk Stratification and Patient Self-Management Tools. As seen in figures 1, 2, $3 \& 4$ here.

\begin{tabular}{|c|c|c|c|c|c|c|}
\hline \multicolumn{7}{|c|}{ Predictive Modeling and Risk Stratification } \\
\hline Author, date & Title & Learning model & Training data/ validation data/ features & Testing data/ features & Study outcomes & Model performance application \\
\hline Han L, 2015 & $\begin{array}{l}\text { Rule Extraction from support Vector } \\
\text { Machine Using Ensemble Learning } \\
\text { Approach: An Application for Diagnosis of } \\
\text { Diabetes }\end{array}$ & $\begin{array}{l}\text { Ensemble learning } \\
\text { using SVM and RF rule } \\
\text { extraction }\end{array}$ & 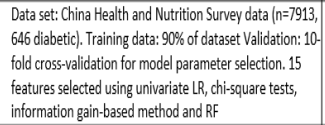 & Test data: remaining $10 \%$ of data & $\begin{array}{l}\text { For positive cases: Precision: } \\
\text { 89.6\% Recall: } 44.3 \% \text {-score: } 0.593 \\
\text { For all cases: Weighted average } \\
\text { precision: } 94.2 \% \text { Weighted } \\
\text { average recall: } 93.9 \% \\
\end{array}$ & $\begin{array}{l}\text { The proposed hybrid system can provide a } \\
\text { tool for the diagnosis of diabetes from } \\
\text { population-based nutritional surveys, and it } \\
\text { supports a second opinion for lay users }\end{array}$ \\
\hline $\begin{array}{l}\text { Shankaracharya, } \\
2012\end{array}$ & $\begin{array}{l}\text { Computational Intelligence-based Diagnosis } \\
\text { Tool for the Detection of Prediabetes and } \\
\text { Type } 2 \text { Diabetes in India }\end{array}$ & $\begin{array}{l}\text { Mixture of expert } \\
\text { system based on MLP }\end{array}$ & $\begin{array}{l}\text { Datata set: } 1415 \text { subjects (947 diabetic) Training data: } \\
\text { 1104/1415 }\end{array}$ & Test data: 311/1415 & $\begin{array}{l}\text { Best result achieved Sensitivity: } \\
\text { 99.5\% specifictity: 99.07\% } \\
\text { Accuracy: } 99.36 \%\end{array}$ & $\begin{array}{l}\text { The proposed tool for identifyjng individuals } \\
\text { with prediabetes, diabetes and nondiabetes } \\
\text { is highly accurate and may be used for large- } \\
\text { scale diabetic screening }\end{array}$ \\
\hline Wei WQ, 2010 & $\begin{array}{l}\text { A High Throughput Semantic Concept } \\
\text { Frequency Based Approatch for Patitent } \\
\text { Identification: A C Case Study Using Type } 2 \\
\text { Diabetes Mellitus Slinical Notes }\end{array}$ & $\begin{array}{l}\text { NLP, SVM and semantic } \\
\text { knowledge }\end{array}$ & $\begin{array}{l}\text { Data set: } 57,707 \text { electronic notes from } 1600 \text { DM patients } \\
\text { and } 1600 \text { control patients in Mayo clinic. Validataion: } 10 \text { - } \\
\text { fold cross-validation for model selection. Features: } \\
\text { Semantic concept units extracted from notes and } \\
\text { classified into semantic type groups }\end{array}$ & No separate test data were specified & $\begin{array}{l}\text { F-score for cases: } 0.956 \text { F-score } \\
\text { for controls: } 0.957 \text { Precision for } \\
\text { cases: } 0.968 . \text { Semantic } \\
\text { knowledge: varying degrees of F- } \\
\text { score, precision, and recall values } \\
\text { reported }\end{array}$ & $\begin{array}{l}\text { The proposed approach is accurate and } \\
\text { responsive to the urgent need to develop a } \\
\text { general automatic approach for diabetic } \\
\text { patient case-finding and characterization }\end{array}$ \\
\hline Corey KE, 2016 & $\begin{array}{l}\text { Development and Validation of an } \\
\text { Algorithm to ldentify Nonalcoholic Fatty } \\
\text { Liver Disease (NAFLC) in the Electronic } \\
\text { Medical Record }\end{array}$ & LR with adaptive LASSO & $\begin{array}{l}\text { Data set: electronic medical records from } 620 \text { patient } \\
\text { randomly selected from the high-risk patients in Partners } \\
\text { Healthare }\end{array}$ & $\begin{array}{l}\text { Test data: randomly selected } 611 \\
\text { high-risk patients identified by } \\
\text { classification algorithm. Additional } \\
\text { validation: independent test set of } \\
314,292 \text { patients. Ground truth: } 100 \\
\text { random positive case record review }\end{array}$ & 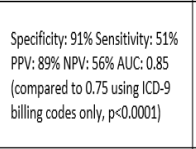 & 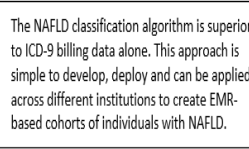 \\
\hline Neves I, 2015 & $\begin{array}{l}\text { A Soft Computing Approach to Kidney } \\
\text { Diabetes Evaluation }\end{array}$ & $\begin{array}{l}\text { Logic Programming, } \\
\text { ANN }\end{array}$ & $\begin{array}{l}\text { Data set: data from } 558 \text { total patients (175 diagnosed with } \\
\text { CKD) Training data: } 2 / 3 \text { of data set Clinical information } \\
\text { about CKO as rewritten into logic Programming } \\
\text { algorithms, and its terms as training and test sets of ANN }\end{array}$ & Test data: remaining $1 / 3$ of data & $\begin{array}{l}\text { ANN performance in test data set } \\
\text { Sensitivity: } 93.19 \% \text { Specificity: } \\
\text { 91.9\% PPV: } 84.4 \% \text { NPV: } 96.6 \%\end{array}$ & $\begin{array}{l}\text { The proposed model showed good } \\
\text { performance in predicting the likelihood of a } \\
\text { CKD diagnosis }\end{array}$ \\
\hline Rau HH., 2016 & $\begin{array}{l}\text { Development of a Web-based Liver Cancer } \\
\text { Prediction Model for Type II Diabetes } \\
\text { Patients by Using an Artificial Neural } \\
\text { Network }\end{array}$ & ANN, LR & $\begin{array}{l}\text { Data set: data from } 2060 \text { diabetic patients in the National } \\
\text { Health Insurance Research Databasese (NHIRD) of Taiman } \\
\text { Training data: } 1442 / 2060\end{array}$ & Test data: $618 / 2060$ & $\begin{array}{l}\text { ANN performance was superior to } \\
\text { that of LR for predicting diabetes } \\
\text { who will be diagnosed with liver } \\
\text { cancer in the next } 6 \text { years. } \\
\text { Sensitivity: } 0.757 \text { specificity: } 0.755 \\
\text { AUC: } 0.873\end{array}$ & $\begin{array}{l}\text { Data mining systems enable clinicians to } \\
\text { predict those diabetics at greater risk for the } \\
\text { development of liver cancer }\end{array}$ \\
\hline Vyas R, 2016 & $\begin{array}{l}\text { Building and Analysis of Protein-Protein } \\
\text { Interactions Related to Diabetes Mellitus } \\
\text { Using Support Vector Machine, Biomedical } \\
\text { Text Mining and Network Analysis }\end{array}$ & SVM & $\begin{array}{l}\text { Training data: positive and negative proteins from PDB } \\
\text { and UniProt databases (n=2653) }\end{array}$ & $\begin{array}{l}\text { Test data: } 129 \text { proteins extracted via } \\
\text { text mining from literature }\end{array}$ & $\begin{array}{l}\text { Accuracy: } 78.20 \% \text { Precision: } \\
\text { 68.26\% AUC: } 0.788\end{array}$ & $\begin{array}{l}\text { This integrated approach has a potential to } \\
\text { identify disease-related proteins, functional } \\
\text { annotation, and other proteomics studies }\end{array}$ \\
\hline Lopez B, 2018 & $\begin{array}{l}\text { Single Nucleotide Polymorphism (SNP) } \\
\text { Relevannee Learning with Random Forests } \\
\text { for Type } 2 \text { Diabetes Risk Prediction }\end{array}$ & Random forest, $k-N N$ & $\begin{array}{l}\text { Data set: data from } 677 \text { subjects (248 diabetic), each } \\
\text { containing } 96 \text { SNPs regarding type } 2 \text { diabetes Features: } \\
\text { SNP data, clinical information, SNP value relevance }\end{array}$ & $\begin{array}{l}\text { Test data: 10-fold cross validation } \\
\text { used. No separate test data were } \\
\text { spectified }\end{array}$ & $\begin{array}{l}\text { For risk prediction AUC: } 0.89 \text { RF } \\
\text { outperformed SVM and LR in } \\
\text { terms of prediction accuracy and } \\
\text { stability of the estimated } \\
\text { relevannce }\end{array}$ & $\begin{array}{l}\text { RF is a useful method for learning predictive } \\
\text { models to help physicians to identify the } \\
\text { relevant SNPS associated with and predictive } \\
\text { of type } 2 \text { diabetes }\end{array}$ \\
\hline
\end{tabular}

Figure 1: Predictive Modeling \& Risk Stratification 
Mr. Mrinmoy Roy / The Advent of Artificial Intelligence in Diabetes Diagnosis: Current Practices and Building Blocks for Future Prospects

\begin{tabular}{|c|c|c|c|c|c|c|}
\hline Author, date & Title & Learning model & Training data/ validation data/ features & Testing data/ features & Study outcomes & Model performance application \\
\hline \multicolumn{7}{|c|}{ Clinical Decision Support } \\
\hline $\begin{array}{l}\text { Lo-Ciganic WH., } \\
2015\end{array}$ & $\begin{array}{l}\text { Using Machine Learning to Examine } \\
\text { Medication Adhherence Thresholds and Risk } \\
\text { of Hospital lization }\end{array}$ & $\begin{array}{l}\text { Random survival } \\
\text { forests, survival trees } \\
\text { models }\end{array}$ & $\begin{array}{l}\text { Data set: } 33,130 \text { non-dual-ligible Medicated enrollees with } \\
\text { type } 2 \text { diabetes. Training data: } 90 \% \text { of data set Features: } \\
\text { sociodemographics, measures of service use, heath status, } \\
\text { diabetes treatment intensity }\end{array}$ & Test data: remaining 10\% data & $\begin{array}{l}\text { The acherence thresholds most } \\
\text { discriminating for risk of all-cause } \\
\text { hospitalization varied from } 46 \% \text { to } \\
94 \% \text { - the widely used } 80 \% \\
\text { adherence threshold is not } \\
\text { optimal for predicting risk of } \\
\text { hospitalization }\end{array}$ & $\begin{array}{l}\text { Machine learning approaches hold promise as } \\
\text { an initututive and powerful approach for } \\
\text { customizing interventions in medication } \\
\text { adherennce in diabetic and optimizing health } \\
\text { outcomes }\end{array}$ \\
\hline Shu T., 2017 & $\begin{array}{l}\text { An Extensive Analysis of Various Texture } \\
\text { Feature Extractors to Detect Diabetes } \\
\text { Mellitus Using Facial Speccitic Regions }\end{array}$ & $\begin{array}{l}\text { k-NN, SVM with } 8 \\
\text { image extractor } \\
\text { methods }\end{array}$ & Data set: 284 diabetes mellitus and 231 heathy samples & $\begin{array}{l}\text { Test data: 10-fold crosss validation } \\
\text { used. No separate test data were } \\
\text { specified }\end{array}$ & $\begin{array}{l}\text { The best texture feature extractor, } \\
\text { Image Gray-scole Histogram (bin } \\
\mathrm{n}=255 \text { ), }\end{array}$ & $\begin{array}{l}\text { Compared with traditional diagnostic methods } \\
\text { that rely on blood samples, the Image Gray- } \\
\text { scale Histogram is a highly accurate, non- } \\
\text { invasive way to diagnose diabetes using facial } \\
\text { and tongugue features. }\end{array}$ \\
\hline Kattgar KM, 2017 & $\begin{array}{l}\text { Fuzzy Expert System for Diagnosing Diabetic } \\
\text { Neuropathy }\end{array}$ & Fuzzy expert tystem & $\begin{array}{l}\text { Data set: diagnostic parameters and their importance } \\
\text { developed by specialilsts used to develop fuzzy expert } \\
\text { system }\end{array}$ & $\begin{array}{l}\text { Test data: } 213 \text { medical records of } \\
\text { patientis dilagnoseded vith dilibetic } \\
\text { neuropathy }\end{array}$ & $\begin{array}{l}\text { For diagnosis and severity of } \\
\text { diabetic neuropathy Senstivivity: } \\
\text { 89\% Specificity: 98\% Accuracy: } \\
93 \%\end{array}$ & $\begin{array}{l}\text { The fuzzy expert system can help diagnose and } \\
\text { determine the severity of diabetic neuropathy }\end{array}$ \\
\hline Wang L., 2017 & $\begin{array}{l}\text { Area Determination of Diabetic Foot Ulcer } \\
\text { Images Using a Cascaded Two-Stage SVM- } \\
\text { Based Classification }\end{array}$ & $\begin{array}{l}\text { Two-stage SVM with } \\
\text { simple linear iterative } \\
\text { clustering and } \\
\text { conditional random } \\
\text { fields }\end{array}$ & Datas set: 100 foot ulcer images from 15 patients & $\begin{array}{l}\text { Test data: cross-validdtion used, No } \\
\text { separatet test data were specified }\end{array}$ & $\begin{array}{l}\text { Sensittity: } 73.3 \% \text {.5pecificity }= \\
94.6 \%\end{array}$ & $\begin{array}{l}\text { Computer-based systems provide high } \\
\text { performance rates for measuring diabetic } \\
\text { wounds and monitoring wound healing status } \\
\text { and ree sufficientity efficient for smartphone- } \\
\text { based image analysis }\end{array}$ \\
\hline
\end{tabular}

Figure 2: Clinical Decision Support

\begin{tabular}{|c|c|c|c|c|c|c|}
\hline Author, date & Title & Learning model & Training data/ validation data/ features & Testing data/ features & Study outcomes & Model performance application \\
\hline \multicolumn{7}{|c|}{ Glucose Sensors and Artificial Pancreas } \\
\hline Mauseth R., 2015 & $\begin{array}{l}\text { Testing of an Artificial Pancreas System } \\
\text { With Pizza and Exercise Leads to } \\
\text { Improvements in the System's Fuzzy } \\
\text { Logic Controller }\end{array}$ & $\begin{array}{l}\text { Fuzzy Logic Controller } \\
\text { systems (FLC) }\end{array}$ & $N / A$ & $\begin{array}{l}\text { Total } 17 \text { meal, } 13 \text { exercise studies } \\
\text { in } 10 \text { subjects with type } 1 \text { diabetes } \\
\text { (TID) FLC V2.0 test: } 9 \text { meal and } 4 \\
\text { exercise studies with FLC V2.0, } \\
\text { followed by interim analysis. FLC } \\
\text { V2.1 test: remaining } 8 \text { meal and } 9 \\
\text { exercise studies using updated FLC }\end{array}$ & $\begin{array}{l}\text { FLCV2.1 showed improvements } \\
\text { in mean blood glucose after } \\
\text { pizza consumption, after } \\
\text { exercise testing, in reducing } \\
\text { hyperglycemia, and percentage } \\
\text { time spent in euglycemic range }\end{array}$ & $\begin{array}{l}\text { Stress testing the AP system followed by } \\
\text { adjustments to the dosing matrix } \\
\text { significantly improved FLC performance } \\
\text { when retested for mean blood glucose, } \\
\text { high blood glucose and normal blood } \\
\text { glucose }\end{array}$ \\
\hline Ling SH., 2012 & $\begin{array}{l}\text { Natural Occurrence of Nocturnal } \\
\text { Hypogy|ycemia Detection Using Hybrid } \\
\text { Particle Swarm Optimized Fuzzy } \\
\text { Reasoning Model }\end{array}$ & $\begin{array}{l}\text { Fuzzy reasoning } \\
\text { model with hybrid } \\
\text { particle swarm } \\
\text { optimization with } \\
\text { wavelet mutation }\end{array}$ & $\begin{array}{l}\text { Data set: } 16 \text { type } 1 \text { diabetic patients Training data: } 320 \\
\text { data points from } 8 / 16 \text { patients }\end{array}$ & $\begin{array}{l}\text { Test data: remaining } 269 \text { data } \\
\text { points from } 8 / 16 \text { patients }\end{array}$ & $\begin{array}{l}\text { Advanced noctural } \\
\text { hypoglycemic episode } \\
\text { detection Sensitivity: } 85.7 \% \\
\text { Specificity: } 79.8 \% \text { Hypoglycemic } \\
\text { episodes detection Sensitivity: } \\
\text { 80.0\% Specificity: } 55.1 \%\end{array}$ & $\begin{array}{l}\text { The proposed system offers a noninvasive } \\
\text { means to detect hypogolycemic episodes in } \\
\text { type } 1 \text { diabetic patients }\end{array}$ \\
\hline Herrero $P_{n}, 2015$ & $\begin{array}{l}\text { Advanced Insulin Bolus Advisor Based on } \\
\text { Run-To-Run Control and Case-Based } \\
\text { Reasoning }\end{array}$ & $\begin{array}{l}\text { Combination of R2R } \\
\text { and CBR }\end{array}$ & $N / A$ & $\begin{array}{l}\text { In silico testing using commercial } \\
\text { type } 1 \text { diabetes simulator } \\
\text { generated 1-month data for } 10 \\
\text { adolescents scenarios }\end{array}$ & $\begin{array}{l}\text { Using CBR(R2R), mean blood } \\
\text { glucose improved in both adult } \\
\text { and adolescent populations and } \\
\text { hypoglycemia was completely } \\
\text { eliminated (R2R alone was not } \\
\text { able to do it in the adolescent } \\
\text { population) }\end{array}$ & $\begin{array}{l}\text { The proposed smartphone system keeps } \\
\text { the simplicity of a standard bolus } \\
\text { calculator while enhancing its performance } \\
\text { by providing more adaptibility and } \\
\text { flexibility }\end{array}$ \\
\hline $\begin{array}{l}\text { Deloumett L, } \\
2016\end{array}$ & $\begin{array}{l}\text { In Silico Testing of an Artificizil- } \\
\text { Intelligence-Based Artificial Pancreas } \\
\text { Designed for Use in the Intensive Care } \\
\text { Unit Setting }\end{array}$ & $\begin{array}{l}\text { Knowledge-based } \\
\text { system }\end{array}$ & $N / A$ & $\begin{array}{l}\text { In silico analysis: } 126000 \text { unique 5- } \\
\text { day simulations resulting in } 107 \\
\text { million glucose values }\end{array}$ & $\begin{array}{l}\text { On average, time in control } \\
\text { range was } 94.2 \% \text {, time in range } \\
70-140 \mathrm{mg} / \mathrm{dl} \text { was } 97.8 \% \text {, time } \\
\text { in hyperglycemic range was } \\
0.09 \% \text { Average coefficient of } \\
\text { variation: } 11.1 \%\end{array}$ & $\begin{array}{l}\text { An Al-based closed-loop glucose controller } \\
\text { may be able to improve on results } \\
\text { achieved by currently existing ICU-based } \\
\text { PID/ MPC controllers }\end{array}$ \\
\hline
\end{tabular}

Figure 3: Glucose Sensors and Artificial Pancreas 


\begin{tabular}{|c|c|c|c|c|c|c|}
\hline Author, date & Title & Learning model & Training data/ validation data/ features & Testing data/ features & Study outcomes & Model performance application \\
\hline \multicolumn{7}{|c|}{ Patient Diabetes Self-Management Tools } \\
\hline Zhang W., 2015 & $\begin{array}{l}\text { "Snap-n-Eat": Food Recognition and } \\
\text { Nutrition Estimation on a Smartphone }\end{array}$ & SVM & $\begin{array}{l}\text { Data set: } 2000 \text { food images comprising } 15 \text { predefined } \\
\text { categories Ground truth: manual annotation }\end{array}$ & Test data: 5-fold cross validation & Accuracy: $85 \%$ & $\begin{array}{l}\text { The proposed smartphone mobile system } \\
\text { can recognize food items present on a } \\
\text { plate and estimates their calorific and } \\
\text { nutrition content, automatically helping } \\
\text { diabetic patients make more informed } \\
\text { food choice decisions. }\end{array}$ \\
\hline Cvetkovic B, 2016 & $\begin{array}{l}\text { Activity Recognition for Diabetic Patients } \\
\text { Using a Smartphone }\end{array}$ & $\begin{array}{l}\text { Ensemble of models } \\
\text { (5VM, ,48, random } \\
\text { forest, Jrip, AdaBoost } \\
\text { and Bagging } \\
\text { algorithms), symbolic } \\
\text { rules }\end{array}$ & $\begin{array}{l}\text { Data set: average } 11 \text { hours of phone and } 7.5 \text { hours of } \\
\text { ECG recordings per day for } 2 \text { weeks from } 9 \text { healthy } \\
\text { volunteers. Training data: first week of recordinggs } \\
\text { Features (ff present): sound, location, acceleration, } \\
\text { heart-rate, respiration-rate }\end{array}$ & $\begin{array}{l}\text { Test data: second week of } \\
\text { recordings }\end{array}$ & $\begin{array}{l}\text { Best result achieved by Multi- } \\
\text { Classifier Adaptive Training } \\
\text { (MCAT) method. Accuracy: } \\
\text { 83.4\% F-score: } 0.82\end{array}$ & $\begin{array}{l}\text { Smartphone sensors using machine } \\
\text { learning and symbolic reasoning can } \\
\text { recognize and quantify high-level lifestyle } \\
\text { activities of diabetic patients and help } \\
\text { them make more informed activity } \\
\text { choices. }\end{array}$ \\
\hline Wang L., 2015 & $\begin{array}{l}\text { Smartphone based Wound Assessment } \\
\text { System for Patients with Diabetes }\end{array}$ & $\begin{array}{l}\text { Image boundary } \\
\text { detection: mean-shift } \\
\text { segmentation } \\
\text { algorithm Color } \\
\text { segmentation: } k \text { - } \\
\text { means clustering }\end{array}$ & $N / A$ & $\begin{array}{l}\text { 30 simulated wound images, } 34 \\
\text { actual patient wound images }\end{array}$ & $\begin{array}{l}\text { Visual evaluation for simulated } \\
\text { images Mathews Correlation } \\
\text { Coefficient: } 0.736\end{array}$ & $\begin{array}{l}\text { The proposed smartphone camera system } \\
\text { enables diabetic patients and their } \\
\text { caregivers to take a more active role in } \\
\text { daily wound care }\end{array}$ \\
\hline Rigla M., 2018 & $\begin{array}{l}\text { Gestational Diabetes Management } \\
\text { (GDM) Using Smart Mobile Telemedicine }\end{array}$ & $\begin{array}{l}\text { Mobile telemedicine } \\
\text { system }\end{array}$ & NA & $\begin{array}{l}20 \text { patients cliagnosed with GDM } \\
\text { (Parallel observational } \\
\text { prospectively captured dinical data } \\
\text { for historical control) }\end{array}$ & $\begin{array}{l}\text { Metabolic and perinatal } \\
\text { outcomes were similar except } \\
\text { for } B P \text {, which was lower in } \\
\text { patients using the telemedicine } \\
\text { system }\end{array}$ & $\begin{array}{l}\text { Artificial-intelligence-augmented } \\
\text { telemedicine has been proposed as a } \\
\text { helpful tool to facilitate an efficient } \\
\text { widespread medical assistance to GDM }\end{array}$ \\
\hline
\end{tabular}

Figure 4: Patient Diabetes Self-Management Tools

\section{References}

International Diabetes Federation, IDF Diabetes Atlas eighth ed Brussels, Belgium International Diabetes Federation, 2017, July 2019, http://www.diabetesatlas.org.

R. M. Anjana, on behalf of the ICMR-INDIAB Collaborative Study Group, R. Pradeepa, et al., "Prevalence of diabetes and prediabetes (impaired fasting glucose and/or impaired glucose tolerance) in urban and rural India: phase I results of the Indian Council of Medical Research-INdia DIABetes (ICMR-INDIAB) study," Diabetologia, vol. 54, no. 12, pp. 3022-3027, 2011.

K. N. Kumar, S. Katkuri, and I. Ramyacharitha, "A study to assess prevalence of diabetes mellitus and its associated risk factors among adult residents of rural Khammam," International Journal Of Community Medicine And Public Health, vol. 5, no. 4, pp. 1360-1365, 2018.

M. Y. Donath, "Targeting inflammation in the treatment of type 2 diabetes: time to start," Nature Reviews Drug Discovery, vol. 13, no. 6, pp. 465-476, 2014.

Medical Council of India. New Delhi. Available from: http://www. mciindia.org/home.aspx. [Last accessed on 2019 Nov 10].

World Health Organization. World Health Statistics 2019. Part II: Global Health Indicators. Geneva: World Health Organization; 2019

Trikkalinou A, Papazafiropoulou AK, Melidonis A. Type 2 diabetes and quality of life. World J Diabetes 2017; 8(4): 120-129 Available from: URL: http://www.wjgnet.com/1948-9358/full/ v8/i4/120.htm DOI: http://dx.doi.org/10.4239/wjd.v8.i4.120

Liu J, Wang R, Ganz ML, Paprocki Y, Schneider D, Weatherall J. The burden of severe hypoglycemia in type 2 diabetes. Curr Med Res Opin 2018; 34:179-186. 
Centers for Disease Control and Prevention. Estimates of diabetes and its burden in the United States. Washington, DC: US Department of Health and Human Services, 2017: 1-20.

The Diabetes Control and Complication Trial Research Group. The effect of intensive treatment of diabetes on the development and progression of long-term complications in insulin-dependent diabetes mellitus. $N$ Engl J Med 1993; 329:977-986.

Latts L. ADA/IBM Watson Health Study $(\mathrm{N}>300,000)$ finds that nearly $60 \%$ of people with T2D discontinue therapy after one year. Presented at: American Diabetes Association 78th Scientific Session, June 22-26, 2018, Orlando, FL.

National Center for Biotechnology Information; US National Library ofMedicine. PubMed. https://www.ncbi.nlm.nih.gov/ pubmed/ Accessed July 18, 2018.

Lewis K. Humans and systems: creating natural interfaces to augment human ability. https://www.ibm.com/blogs/internetof- things/creating-natural-interfaces/ Accessed July 18, 2018.

Aggarwal M, Madhukar M. IBM's Watson analytics for health care: a miracle made true. Hershey, $P A$ : IGI Global, 2016:117-134.

Turing Archive for the History of Computing. www.alanturing.net/turing_archive/archive/index/archiveindex.html Accessed July 18, 2018.

Research 2 Guidance. Top 3 therapy fields with the best market potential for digital health apps. https://research2guidance.com/top-3-therapy-fields-with-the-best-marketpotential-for-digital-health-apps/ Accessed July 18, 2018.

Yeung S, Downing NL, Fei-Fei L, Milstein A. Bedside computer vision-moving artificial intelligence from driver assistance to patient safety. N Engl J Med 2018; 378:1271-1273.

Young K. Newly approved software uses AI to improve diabetic retinopathy. https://www.jwatch.org/fw114063/2018/04/12/newly-approved-software-uses-ai-detect-diabetic Accessed July $18,2018$.

Pfaffl MW. A new mathematical model for relative quantification in real-time RT-PCR. Nucleic Acids Res $2001 ; 29: 45 \mathrm{e}$.

Lo'pez B, Martin C, Viñas PH. Special section on artificial intelligence for diabetes. Artif Intell Med 2018; $85: 27-28$.

Raghupathi W, Raghupathi V. Big data analytics in healthcare: promise and potential. Health Inf Sci Syst 2014; $2: 3$.

Hoyt RE, Snider D, Thompson C, Mantravadi S. IBM Watson analytics: automating visualization, descriptive, and predictive statistics. JMIR Public Heal Surveill 2016; 2:e157.

Vijan S, Hofer TP, Hayward RA. Cost-utility analysis of screening intervals for diabetic retinopathy in patients with type 2 diabetes mellitus. JAMA 2000; 283:889-896.

Gulshan V, Peng L, Coram M, et al. Development and validation of a deep learning algorithm for detection of diabetic retinopathy in retinal fundus photographs. JAMA 2016; 316:2402-2410.

Tariq A, Akram MU, Shaukat A, Khan SA. Automated detection and grading of diabetic maculopathy in digital retinal images. J Digit Imaging 2013; 26:803-812.

Rahim SS, Palade V, Shuttleworth J, Jayne C. Automatic screening and classification of diabetic retinopathy fundus images. In: Mladenov V, Jayne C, Iliadis L, eds. Engineering applications of neural networks. Communications in computer and information science. Vol 459. Basel, Switzerland: Springer Nature Switzerland AG, 2014:113-122.

Lam C, Yu C, Huang L, Rubin D. Retinal lesion detection with deep learning using image patches. Invest Ophthalmol Vis Sci 2018; 59:590-596.

US Food and Drug Administration. FDA permits marketing of artificial intelligence-based device to detectcertain diabetes-related eye problems. https://www.fda.gov/ NewsEvents/Newsroom/PressAnnouncements/ucm604357.htm Accessed July 18, 2018.

Keel S, Lee PY, Scheetz J, et al. Feasibility and patient acceptability of a novel artificial intelligence-based screening model for diabetic retinopathy at endocrinology outpatient services: a pilot study. Sci Rep 2018; $8: 4330$. 
Matimba A, Woodward R, Tambo E, Ramsay M, Gwanzura L, Guramatunhu S. Tele-ophthalmology: opportunities for improving diabetes eye care in resource- and specialist limited Sub-Saharan African countries. $J$ Telemed Telecare 2016; 22:311-316.

Han L, Luo S, Yu J, Pan L, Chen S. Rule extraction from support vector machines using ensemble learning approach: an application for diagnosis of diabetes. IEEE J Biomed Health Inform 2015; 19:728-734.

Shankaracharya, Odedra D, Samanta S, Vidyarthi AS. Computational intelligence-based diagnosis tool for the detection of prediabetes and type 2 diabetes in India. Rev Diabet Stud 2012; 9:55-62.

Wei W-Q, Tao C, Jiang G, Chute CG. A high throughput semantic concept frequency-based approach for patient identification: a case study using type 2 diabetes mellitus clinical notes. AMIA Annu Symp Proc 2010; 2010:857-861. TRANSFORMING DIABETES CARE THROUGH AI 241

Corey KE, Kartoun U, Zheng H, Shaw SY. Development and validation of an algorithm to identify nonalcoholic fatty liver disease in the electronic medical record. Dig Dis Sci 2016; 61:913-919.

Neves J, Martins MR, Vilhena J, et al. A soft computing approach to kidney diseases evaluation. J Med Syst $2015 ; 39: 131$.

Rau H-H, Hsu C-Y, Lin Y-A, et al. Development of a web-based liver cancer prediction model for type II diabetes patients by using an artificial neural network. Comput Methods Programs Biomed 2016; 125:58- 65.

Weber C, Neeser K. Using individualized predictive disease modeling to identify patients with the potential to benefit from a disease management program for diabetes mellitus. Dis Manag 2006; 9:242-256.

Vyas R, Bapat S, Jain E, Karthikeyan M, Tambe S, Kulkarni BD. Building and analysis of protein-protein interactions related to diabetes mellitus using support vector machine, biomedical text mining, and network analysis. Comput Biol Chem 2016; 65:37-44.

Lo'pez B, Torrent-Fontbona F, Viñas R, Ferna'ndez-Real JM. Single nucleotide polymorphism relevance learning with random forests for type 2 diabetes risk prediction. Artif Intell Med 2018; 85:43-49.

Lo-Ciganic WH, Donohue JM, Thorpe JM, et al. Using machine learning to examine medication adherence thresholds and risk of hospitalization. Med Care 2015; 53:720-728.

Shu T, Zhang B, Yan Tang Y. An extensive analysis of various texture feature extractors to detect diabetes mellitus using facial specific regions. Comput Biol Med 2017; 83: 69-83.

Katigari MR, Ayatollahi H, Malek M, Haghighi MK. Fuzzy expert system for diagnosing diabetic neuropathy. World J Diabetes 2017; 8:80-88.

Wang L, Pedersen PC, Agu E, Strong DiM, Tulu B. Area determination of diabetic foot ulcer images using a cascaded two-wtage SVM-based classification. IEEE Trans Biomed Eng 2017; 64:2098-2109.

Mauseth R, Lord SM, Hirsch IB, Kircher RC, Matheson DP, Greenbaum CJ. Stress testing of an artificial pancreas system with pizza and exercise leads to improvements in the system's fuzzy logic controller. $J$ Diabetes Sci Technol 2015; 9:1253-1259.

Ling SH, Nguyen HT. Natural occurrence of nocturnal hypoglycemia detection using hybrid particle swarm optimized fuzzy reasoning model. Artif Intell Med 2012; 55: 177-184.

Herrero P, Pesl P, Reddy M, Oliver N, Georgiou P, Toumazou C. Advanced insulin bolus advisor based on runtorun control and case-based reasoning. IEEE J Biomed Health Inform 2015; 19:1087-1096.

DeJournett L, DeJournett J. In silico testing of an artificialintelligence-based artificial pancreas designed for use in the intensive care unit setting. J Diabetes Sci Technol 2016; 10:1360-1371.

Thabit H, Tauschmann M, Allen JM, et al. Home use of an artificial beta cell in type 1 diabetes. $N$ Engl J Med 2015; 373:2129-2140.

Trevitt S, Simpson S, Wood A. Artificial pancreas device systems for the closed-loop control of type 1 diabetes: what systems are in development? J Diabetes Sci Technol 2016; 10:714-723.

Zhang W, Yu Q, Siddiquie B, Divakaran A, Sawhney H."Snap-n-Eat": food recognition and nutrition estimation on a smartphone. J Diabetes Sci Technol 2015; 9:525-533. 
Cvetkovic' B, Janko V, Romero AE, Kafalı O”, Stathis K, Lus`trek M. Activity recognition for diabetic patients using a smartphone. J Med Syst 2016; 40:256.

Wang L, Pedersen PC, Strong DM, Tulu B, Agu E, Ignotz R. Smartphone-based wound assessment system for patients with diabetes. IEEE Trans Biomed Eng 2015; 62:477-488.

Rigla M, Martı'nez-Sarriegui I, Garcı'a-Sa'ez G, Pons B, Hernando ME. Gestational diabetes management using smart mobile telemedicine. J Diabetes Sci Technol 2018; 12:260-264.

ClinicalTrails.gov. Adult accuracy study of the Elite 3 Glucose Censor (E3). https://www.clinicaltrials.gov/ct2/show/study/NCT02246582?term=NCT02246582\&rank=1\&sect=X0123456 Accessed July 18, 2018.

Neemuchwala H. Sugar.IQ improves time-in-range by $36 \mathrm{mins} /$ day, time $>180$ by $30 \mathrm{mins} /$ day, time $<70$ by 6mins/day. Presented at: American Diabetes Association 78th Scientific Session, June 22-26, 2018, Orlando, FL.

Benson T. Principles of health interoperability HL7 and SNOMED, 2nd edition. London: Springer Verlag, 2012.

Adler-Milstein J, DesRoches CM, Kralovec P, et al. Electronic health record adoption in us hospitals: Progress continues, but challenges persist. Health Aff (Millwood) 2015;34:2174-2180.

Hutson TM. Missing data hinder replication of artificial intelligence studies. www.sciencemag.org/news/2018/02/missing-data-hinder-replication-artificial-intelligence-studies? Accessed July 18, 2018. 